\title{
Clinical, haematological and some biochemical variations hypophosphataemia in buffaloes before and after treatment at Assiut Government
}

\author{
M. E Radwan ${ }^{1 *}$, H. Z. Rateb ${ }^{2}$ \\ ${ }^{1}$ Animal Health Research Institute., Assiut Regional Laboratory. \\ ${ }^{2}$ Department of Animal Medicine, Faculty of Veterinary Medicine, Assiut University.
}

\begin{abstract}
A total number of 28 buffaloes aged between 5-7years, body weight ranged between $400-500 \mathrm{~kg}$, and belonged to private farms at Assiut Governorate constituted the materials of this study. Twenty of them showed the classical signs of hypophosphataemia while the other eight buffaloes were proved to be healthy by both clinical and laboratory investigations, used as control group. Biochemical analysis of blood sera showed a highly significant hypophosphataemia, hypocalcaemia and hypomagnesaemia in diseased buffaloes either pre or post treatment when compared with the healthy control ones. Meanwhile, the examination of blood showed marked decreases in erythrocytic count, haemoglobin concentration and packed cell volume in diseased animals. All parameters improved in affected buffaloes after 10 days of treatment. The chemical analysis of agronomical samples of soil and drinking water were done. The statistical analyses between the studied parameters were carried out in buffaloes before and after treatment.
\end{abstract}

Hypophosphataemia is a well-known metabolic disorder of cattle and buffaloes resulted from deficiency of phosphorous or imbalance in Ca:P ratio. Phosphorus deficiency leading to hypophosphataemia may play a part in haemoglobinurea by decreasing red cell glycolysis and ATP synthesis. It is a sporadic disease affecting high ratio of buffaloes, and considered to be of dietary origin, as a result of prolonged feeding on barseem (Nassif, 1995; Selim et al., 1998; Rizk et al., 1999).

Hypophosphataemia affects recently calved and heavey lactating buffaloes. Buffaloes at the $3^{\text {rd }}$ to $6^{\text {th }}$ lactations are most commonly affected. The disease usually appears in the period from $2^{\text {nd }}$ to $4^{\text {th }}$ weeks after calving, it was considered that there was much more drainage of this element through milk (Chugh et al., 1998 and Abdul Samad, 1997). The pregnancy stress indicates that buffaloes from the $7^{\text {th }}$ month of pregnancy have a significant wider ratio of blood $\mathrm{Ca}: \mathrm{P}$ than those the earlier stages of pregnancy (Pirzada et al., 1998).

Many authors pointed that the higher

* Corresponding author. Tel.: +20 0102994881

(M.E Radwan). incidence of hypophosphataemia in buffaloes occurs from May to January which coincides with the late pregnancy and early post-parturient periods as the majority of buffaloes either in late stage of pregnancy or early post parturient stage during these months.

The mechanism by which the interavascular hemolysis occurs has not fully defined. Several predisposing factors are included such as recent parturition, inadequate dietary phosphorous intake and/or high calcium ratio, copper deficiency, drinking of cold water or exposure to extreme coldness (Smith, 1996 and Chugh et al.,1998). Faqing et al., (2002) speculated that the constituents of phospholipids in the erythrocyte membrane, the protein in the membrane skeleton and the form of erythrocyte changes when haemolysis occurs in the cow with low phosphorus intake.

The deficiency of phosphorus causes loss of appetite, referred as 'Pica', which symptomized by eating bones, manure, placenta and other materials like clothes and wood. This commonly occurs in animals grazing on soils low in phosphorus as a results of which the forage grown with low in 
phosphorus (Pirzada et al.,1998). The other most prominent clinical symptoms related to phosphorous deficiency were haemoglobinuria (coffe-coloured urine), pale mucous membranes of conjunctiva and vulva, sharp decrease in milk yield and constipation with constricted sphincter ani accompanied with either normal or subnormal body temperature (Selim et al., 1998 ; Rizk et al.,1999). The most prominent symptoms of hypophosphataemia in buffaloes include hemoglobinuria, inappetance, depression of milk yield, the mucous membranes are palled, weakness associated with osteomalacia, muscles weakness, lameness, locomotor disturbances, staggering gait. Recumbency occurs later in severe hypophosphatemic animals (El-Magawry et al., 1995; Rizk et al., 1999; Hoda, 2006). There is also, labored respiration with acceleration of pulse and jugular pulsation .Finally the affected animals with severe hypophosphataemia may die from anemic hypoxia or anoxia (Smith, 1996). The phosphorus deficiency in buffaloes is one of the most important causes of ovarian inactivity among Egyptian cows and buffaloes (Nassif, 1995).

The level of serum inorganic phosphorus in buffaloes with haemoglobinuria was very low $(0.9 \mathrm{mg} / 100 \mathrm{ml})$ with a decrease in serum level (Pandy and Misra, 1987).

Selim et al., (1998) proved that the injection of tonophosphan $\mathrm{i} / \mathrm{m} 25 \mathrm{cc}$ once daily in the first two days with $\mathrm{s} / \mathrm{c}$ of $20 \%$ sodium acid phosphate every 12 hours for 5 successive days, in addition with $120 \mathrm{gm}$ disodium phosphate orally once daily for 10 days give good results.

Rizk et al., (1999) treated hypophosphataemic buffaloes with i.v injection of Ringer solution, (1L) together with i.m injection of AD3E $(5 \mathrm{ml} / \mathrm{animal})$ and the dose was repeated after one week. In addition $5 \mathrm{ml}$ Pregazole followed i.v. slow injection of $1 \mathrm{~L}$ of dextrose solution (5\%) containing $30 \mathrm{gm}$ dihydrogen phosphate were also used. In fatal cases, blood transfusion is recommended (Hotter and Buchner, 1995).

Magnesium is considered to be the major intracellular divalent cation and it is an essential element among a number of enzymatic activities in the body including phosphates and enzymes that involve ATP. The action of magnesium extends to all major anabolic and catabolic processes. Magnesium plays a vital role in muscle contraction, protein, fat and carbohydrate metabolism, function properties and immune responses (Kaneko et al., 1997; Radostitis, et al., 2003).

The absorption of phosphorous from the reticulorumen is severely reduced as in dietary phosphorous deficiency. The absorption of both $\mathrm{Ca}$ and $\mathrm{Mg}$ from the reticulorumen becomes impaired (Care, 1994). Kaneko et al., (1997) added that magnesium interacts with extra cellular $\mathrm{Ca}$ by binding to many shared ligaments. In general $\mathrm{Mg}$ acts as a $\mathrm{Ca}$ antagonist. Magnesium binds to chief cells in the parathyroid gland and inhibits secretion of parathyroid hormones. Goff, (1999) noticed that the majority of the calcium, phosphorous and magnesium balance disorders are due to low blood concentrations of these minerals.

Analysis of blood in hypophosphataemic buffaloes showed marked decrease in erythrocytic count, hemoglobin concentration and packed cell volume. Observed improvement in these parameters occurs in affected buffaloes after 10 days of treatment due to increased level of blood phosphorus resulting into cessation of haemolysis. (Abdou et al., 1999; Mobark and El-Bealawy, 2002)

Preventive measures could be taken to reduce the incidence of hypophosphataemia in buffaloes. Ration in the beginning days of lactation must be quantitatively sufficient in phosphorus content. The minimum daily requirement of buffaloes (450kg.) for phosphorus as phosphate is $22 \mathrm{gm} /$ day producing about $7.5 \mathrm{~kg} \mathrm{milk/day} \mathrm{is} \mathrm{adequate}$ (Harris et al., 1990; Radostitis et al., 2003).

This study amid to throw light upon clinical, haematological and some biochemical alteration in buffaloes suffered from hypophosphstaemia associated with trials of treatment.

\section{Materials and Methods}

Animals. A total number of 28 buffaloes aged between 5-7 years old with body weight ranged between $400-500 \mathrm{~kg}$. Animals are belonged to private farms at Assiut Governorate. The study extended between October 2006 to January 2007. Twenty of examined buffaloes showed the classical signs of hypophsphataemia and divided to three groups, each one took different treatment. Another eight clinically and healthy buffaloes were used as a control. These animals were subjected to careful clinical and laboratory examination to ensure their healthy status and used as control. 
Blood samples. Two blood samples were obtained from each animal by a jugular vein puncture one without anti-coagulant before and after treatment to obtain clear non-haemolysed sera, which used for biochemical studies. The obtained sera were used for determination of magnesium, calcium and phosphorus using test-kits after the methods described by Bohuon (1962), Gindler (1972) and Goldenberg (1966) respectively. Another blood samples with anti-coagulant (before and after treatment), were used for haematological studies (total erythrocytic count, hemoglobin concentration and packed cell volume) according to the methods described by Schalm (1986).

Soil samples. Samples were collected from the top $20 \mathrm{~cm}$ of soil. $500 \mathrm{gm}$ of the soil was bagged in clean dry nylon bag (Page, 1982). For chemical analysis of agronomical samples, the soil samples were washed by using ammonium bicarbonate for extraction of inorganic phosphorus (Soltan, 1985). Ammonium acetate (Normal) was used to extract calcium (Lindsay and Norvell, 1969).

Water samples. Two samples are taken, one is from tap water (supplied by the General Organization for Drinking Water and Sanitary Drainage) and another from the underground water. Water samples were subjected to collected estimation of their phosphorous, calcium and magnesium levels.

Examination of urine. Voided urine samples from diseased buffaloes were examined for detection of dark red brown to black in color (coffee colored urine of varying intensities). Hemoglobinuria were noticed by allowing urine to stand and settle according to the methods described by Schalm, 1986.

Treatment trials. The diseased animals were treated by using different lines of treatment to evaluate the best line that could improve the clinical, haematological and biochemical parameters. In the first group $60 \mathrm{gm}$ of dibasic sodium phosphate (El-GomhouriaCo.) were dissolved in $300 \mathrm{ml}$ normal saline and given $\mathrm{i} / \mathrm{v}$. in addition to $60 \mathrm{gm}$ of dibasic sodium phosphate dissolved in $300 \mathrm{ml}$ normal saline given $\mathrm{s} / \mathrm{c}$ for the first three days followed by $60 \mathrm{gm}$ orally for seven days. In the second group, $50 \mathrm{ml}$ tonophosphan solution 20\% (Intervet Egypt Co.) was given i/v plus $25 \mathrm{ml} \mathrm{i/m}$ and $25 \mathrm{ml} \mathrm{s} / \mathrm{c}$ for five days. In third group, $60 \mathrm{gm}$ of monobasic sodium phosphate (ElGomhouria Co.), dissolved in $300 \mathrm{ml}$ normal saline given $\mathrm{i} / \mathrm{v}$. in addition to $60 \mathrm{gm}$ of monobasic sodium phosphate dissolved in $300 \mathrm{ml}$ normal saline given s/c for five days, followed by $60 \mathrm{gm}$ orally for seven days.

Statistical analysis. The obtained results were analyzed statistically according to Selvin, (1996).

\section{Results}

Clinical symptom. Clinical examination of buffaloes suffering from hypophosphataemia showed voiding of coffee coloured urine, sharp decreased in milk yield, partial to depraved appetites, anemia (manifested by pale and icteric mucous membranes), weakness, accelerated pulse and respiratory rates with decreased in normal to slightly increased in body temperature, dullness and decreased ruminal stasis, and constipation with straining appears.

The clinical symptoms of haemoglobinuria disappeared within two days in the first group of treatment. Within 4-5 days, the symptoms disappeared in the second group of treatment and the symptoms disappeared after 6 days in the last treated group of diseased buffaloes and animals return to normal.

Biochemical analysis of blood serum phosphorous, magnesium, and calcium. Blood serum inorganic phosphate, calcium and magnesium levels showed significant decrease in hypophosphataemic buffaloes and these parameters reached to near the normal values after treatment in all treated group (Table, 1, 2, 3).

The haematological picture of RBCs, Hb and PCV. The examination of blood samples in hypophosphataemic buffaloes revealed a highly significant oligocythaemia in red cell count, haemoglobin concentration and packed cell volume when compared with healthy ones. Marked improvement began gradually following treating trials which reached near to the normal values after treatment (Table 1, 2, 3).

Urine analysis. Examination of the urine revealed passing of coffee coloured urine usually clear after centrifugation. Sediment retained uniform clear red colour without blood clotted or pus cells and no strong ammoniacal odder.

Chemical analysis of agronomical samples. Phosphorous, calcium and magnesium 
Table (1): Biochemical analysis of blood serum phosphorus, magnesium and calcium levels and some haematological parameters in hypophosphataemic buffaloes before and after treatment with dibasic sodium phosphate.

\begin{tabular}{lccc}
\hline Parameters & Control & $\begin{array}{c}\text { Hypophosphataemic } \\
\text { buffaloes before } \\
\text { treatment }\end{array}$ & $\begin{array}{c}\text { Hypophosphataemic } \\
\text { buffaloes after } \\
\text { treatment }\end{array}$ \\
\hline Phosphorous mg\% & $5.82 \pm 0.08$ & $4.92 \pm 0.80^{*}$ & $5.82 \pm 0.08$ \\
Magnesium mg\% & $(5.80-6.00)$ & $(4.60-5.40)$ & $(5.80-6.00)$ \\
Calcium mg\% & $6.12 \pm 1.03$ & $4.97 \pm 0.60^{* *}$ & $6.12 \pm 1.03$ \\
& $(6.50-7.80)$ & $(4.50-5.57)$ & $(6.50-7.80)$ \\
RBCs T/L & $9.96 \pm 0.14$ & $8.42 \pm 0.26^{*}$ & $9.96 \pm 0.14$ \\
& $(8.10-10.99)$ & $(7.61-8.70)$ & $(8.10-10.99)$ \\
Hb gm\% & $9.34 \pm 0.14$ & $5.04 \pm 0.11^{* *}$ & $9.34 \pm 0.14$ \\
& $(8.90-10.15)$ & $(4.60-5.70)$ & $(8.90-10.15)$ \\
PCV \% & $12.05 \pm 0.2$ & $8.32 \pm 0.18^{* *}$ & $12.05 \pm 0.2$ \\
& $(11.40-13.10)$ & $(7.60-9.40)$ & $(11.40-13.10)$ \\
& $32.85 \pm 1.15$ & $26.60 \pm 1.10^{* *}$ & $32.85 \pm 1.15$ \\
& $(30.00-38.00)$ & $(25.00-28.00)$ & $(30.00-38.00)$ \\
\hline
\end{tabular}

* Significant at $\mathrm{p}<0.05$.

** Highly significant $\mathrm{p}<0.01$.

$\mathrm{T} / \mathrm{L}=10^{12} / \mathrm{L}$

Table (2): Biochemical analysis of blood serum phosphorus, magnesium and calcium levels and some haematological parameters in hypophosphataemic buffaloes before and after treatment with Tonophosphan.

\begin{tabular}{lccc}
\hline Parameters & Control & $\begin{array}{c}\text { Hypophosphataemic } \\
\text { buffaloes before } \\
\text { treatment }\end{array}$ & $\begin{array}{c}\text { Hypophosphataemic } \\
\text { buffaloes after } \\
\text { treatment }\end{array}$ \\
\hline Phosphorous mg\% & $5.82 \pm 0.08$ & $4.34 \pm 0.06^{*}$ & $6.26 \pm 0.29$ \\
Magnesium mg\% & $(5.80-6.00)$ & $(4.00-4.80)$ & $(5.60-7.50)$ \\
Calcium mg\% & $6.12 \pm 1.03$ & $5.65 \pm 0.21^{*}$ & $6.10 \pm 0.93$ \\
& $(6.50-7.80)$ & $(4.51-6.36)$ & $(5.04-6.98)$ \\
RBCs T/L & $9.96 \pm 0.14$ & $8.18 \pm 0.05^{*}$ & $9.50 \pm 0.27$ \\
& $(8.10-10.99)$ & $(7.11-9.25)$ & $(9.24-10.50)$ \\
Hb gm\% & $9.34 \pm 0.14$ & $4.60 \pm 0.15^{* *}$ & $6.16 \pm 0.16^{*}$ \\
PCV \% & $(8.90-10.15)$ & $(3.80-5.20)$ & $(5.20-6.80)$ \\
& $12.05 \pm 0.2$ & $7.40 \pm 0.25^{* *}$ & $8.30 \pm 0.01^{*}$ \\
& $(11.40-13.10)$ & $(6.80-8.50)$ & $(11.40-13.10)$ \\
& $32.85 \pm 1.15$ & $24.00 \pm 1.50^{* *}$ & $27.00 \pm 1.95^{*}$ \\
& $(30.00-38.00)$ & $(2300-26.00)$ & $(26.00-29.00)$ \\
\hline
\end{tabular}

* Significant at $\mathrm{p}<0.05$.

** Highly significant $\mathrm{p}<0.01$.

$\mathrm{T} / \mathrm{L}=10^{12} / \mathrm{L}$ 
Table (3): Biochemical analysis of blood serum phosphorus, magnesium and calcium levels as well as some haematological parameters in hypophosphataemic buffaloes before and after treatment with monobasic sodium phosphate.

\begin{tabular}{lccc}
\hline Parameters & Control & $\begin{array}{c}\text { Hypophosphataemic } \\
\text { buffaloes before } \\
\text { treatment }\end{array}$ & $\begin{array}{c}\text { Hypophosphataemic } \\
\text { buffaloes after } \\
\text { treatment }\end{array}$ \\
\hline Phosphorous mg\% & $5.82 \pm 0.08$ & $3.60 \pm 0.60^{* *}$ & $4.95 \pm 0.25^{*}$ \\
Magnesium mg\% & $(5.80-6.00)$ & $(3.50-3.83)$ & $(3.90-4.60)$ \\
& $6.12 \pm 1.03$ & $4.08 \pm 0.19^{* *}$ & $6.03 \pm 0.23$ \\
Calcium mg\% & $(6.50-7.80)$ & $(3.60-4.95)$ & $(5.20-6.80)$ \\
& $9.96 \pm 0.14$ & $8.60 \pm 0.24^{*}$ & $9.60 \pm 0.55$ \\
RBCs T/L & $(8.10-10.99)$ & $(7.66-9.56)$ & $(8.66-10.80)$ \\
& $9.34 \pm 0.14$ & $4.48 \pm 0.17^{* *}$ & $7.82 \pm 0.17^{*}$ \\
Hb gm\% & $(8.90-10.15)$ & $(4.10-5.20)$ & $(6.20-9.10)$ \\
& $12.05 \pm 0.2$ & $7.82 \pm 0.17^{* *}$ & $9.22 \pm 0.32^{*}$ \\
PCV \% & $(11.40-13.10)$ & $(6.20-9.10)$ & $(7.90-9.90)$ \\
\hline
\end{tabular}

* Significant at $\mathrm{p}<0.05$.

** Highly significant $\mathrm{p}<0.01$.

$\mathrm{T} / \mathrm{L}=10^{12} / \mathrm{L}$

Table (4): Chemical analysis of agronomical samples.

\begin{tabular}{lccc}
\hline \multicolumn{1}{c}{ Parameters } & Soil & Tap water & Ground water \\
\hline Phosphorus & $1.27 \pm 0.6$ & $3.50 \pm 0.25$ & $4.00 \pm 0.35$ \\
mg/dl & $(1.09-1.45)$ & $(3.25-3.75)$ & $(3.65-4.35)$ \\
Magnesium & $1.88 \pm 0.93$ & $0.00 \pm 0.00$ & $0.00 \pm 0.00$ \\
mg/dl & $(1.86-1.91)$ & $(0.00-0.00)$ & $(0.00-0.00)$ \\
Calcium mg/dl & $15.79 \pm 0.55$ & $11.95 \pm 0.90$ & $8.40 \pm 0.95$ \\
& $(15.26-16.32)$ & $(11.05-12.85)$ & $(7.55-9.75)$ \\
\hline
\end{tabular}

concentration are determined in soil, tape water and underground water in the area of study (Table 4).

\section{Discussion}

Phosphorus is considered the major important divalent cation, and constituent of bones and teeth of animal body. It is an essential component of nucleic acid DNA and RNA, nucleotides and for enzymatic activities in the body. Phosphate plays a critical role in every cell, tissue and organ and plays more varied role in the chemistry of living organisms.

The most important clinical signs in diseased buffaloes were passing of coffee coloured urine, sharp decreased in milk yield, decreased to depraved appetites. Anaemia was manifested by pale and icteric mucous membranes, weakness accelerated pulse and respiratory rates with decreased to normal or slightly increased in body temperature, dullness and decreased to ruminal stasis, constipation with straining appears. These clinical signs coincided with that previously mentioned by (Udall, 1992; Smith, 1996; Radostitis et al., 2003). Such signs may be attributed to haemolysis of RBCs and decrease in haemoglobin concentration and PCV from increased fragility of erythrocytes leading to haemolysis. Inadequate phosphorus in the plasma leads to decrease ATP synthesis which is essential in maintaining the shape and deformability of RBCs. These results are in agreement with (Nassif 1995; Abdul Samad, 1997; Kaneko et al., 1997; Radostitis et al., 2003). Improvement in affected buffaloes after treatment due to increased level of 
blood phosphorous resulted in cessation of haemolysis from increased fragility of erythrocytes. The reduction of ATP caused the cells being spherical with increased liability to osmotic fragility with subsequent shortening in RBCs life span (Bhikane et al, 1995; Abdul Samad, 1997).

Biochemical analysis of blood serum phosphorous, magnesium, and calcium of buffaloes suffering from hypophosphataemia showed a significant decrease in pre-treated if compared with the treated ones, Similar findings were recorded by (Udal 1992; Smith, 1996; Radostitis et al., 2003), The authors pointed out that a concurrent hypocalcaemia with hypomagnesaemia may have a contributing effect. In many instances rations given to such animals may have very high $\mathrm{Ca}$ but much lower $\mathrm{P}$ contents as in barseem or due to drainage of phosphorus in milk (Smith, 1996; Radostitis et al., 2003). Moreover magnesium deficiency may influence calcium homeostasis. Hypomagnesaemia associated with hypocalcaemia which are contributing factors in many instances may even be the dominant factor. Declined blood serum calcium during pregnancy as a result of large increase in the rate at which foetal skeleton needs $\mathrm{Ca}$ for mineralization and after parturition due to colostrums, needs high level of calcium. All these factors may decreased free blood calcium levels. Similar findings were previously reported by (Pandey and Misra, 1987; El-Magawery et al., 1995).

Biochemichal analysis of soil and tape water as well as ground water revealed a significant decrease in phosphorous and magnesium levels, such decrease may be attributed to the severity of the clinical signs. These results are in agreement with (Mark and Mark 2003).

Attention to phosphorus content in the ration beginning of lactation period. Bone meal, dicalcium phosphate, disodium phosphate and sodium pyrophosphate provided in supplementary feed or allowing free access to their mixture salt. Adding to the pasture super-phosphate in adequate methods to correct the deficiency and advantage the phosphorous content in the plants.

Finally, the study revealed the influence of hypophosphataemia upon the studied parameters. Also trials of treatment of diseased buffaloes alleviate the clinical signs of hypophosphataemia and elevated the levels of the studied parameters in treated animals to be around the normal obtained levels in buffaloes.

\section{References}

Abdou, T.A; Abbas, M. R. and Salman, N. A. (1999): An episode of postparturient hemoglobinuria with Heinz bodies anemia in dairy cattle. $5^{\text {th }}$ Sci. Cong., Egyptian Society for cattle diseases, 28-30 Nov., Assiut, Egypt.

Abdul Samad (1997): Host and environmental factors associated with phosphorous deficiency hemoglobinuria in buffaloes. Buff. J. 13 (3): 385-395.

Bhikane, A. U.; Ali, M. S.; Narladkar, B. W. and Kawithar, S.B. (1995): Post parturient haemoglobinuria in crossed cow and its treatment. Ind. Vet J., 72: 734-736.

Bohuon C. (1962): Colorimetric determination of magnesium. Anal. Chem. Acta. 7: 811-817.

Care, A. D. (1994): The absorption of phosphate from the digestive tract of ruminant animals. Br.Vet.J., 150: 197-205.

Chugh, S. K.; Bhardwaj, R. M. and Mata, M. M. (1998): Lowered antioxidant status of red blood cells in postparturan hemoglobinuria of buffaloes. Vet. Res. Comm., 22: 385-388.

Chugh, S. K.; Matta, M. M. and Malik, K. S. (1998): Epidemiological observations on post parturient haemoglobinuria in buffaloes. Ind. J. Sci. , 66 (11): 11231125.

El-Magawery, S.; Naser, M. H.; Naser, M. Y. and Abo ElEneen, G.E. (1995):Clinico-biochemical and epidemiological aspects of Egyptian buffaloes with trial of treatment. Alex. J. Vet. Sci., 11 (4): 599-606.

Faqing, S.; Dawei, X.; Wei, X. S. and Wei, W. (2002): Molecular mechanism of erythrocytic membrane damage in cow with low phosphorus hemoglobinuria. Chinese J. Vet. Med., 28 (8): 3-8.

Gindler M. (1972): Colorimetric determination of serum calcium. Am. J. Clin. Path., 58: 376-382.

Goff, J. P. (1999): Treatment of calcium, phosphorus and magnesium balance disorders. Vet. Clin. North Am. Food Animal Pract., 15 (3): 619-639.

Goldenberg, H. (1966): Colorimeteric determination of serum phosphorus. Clin. Chem., 12: 871.

Harris, H.; Morse, D.; Head, H. H. and Van Horn, H. H. (1990): Phosphorus nutrition and excretion by dairy animals, one of the series of the dairy science. Cooperative extension service, Institute of food and agricultural sciences, University of Florida, USA.

Hoda, I. M. (2006): Clinico-Biochemical studies on hypophosphataemia in buffaloes with some therapeutic trials. Ph.D. Vet. Med. Assiut Univ., Egypt.

Hotter, V.H. and Buchner (1995): Puerperale hamoglobinurie in einem Milchvieh betrieb (post-parturient haemoglobinuria in a dairy herd) Wien. Tierazth. Mschr., 82: 117-121.

Kaneko, J. J.; Harvey, J. W. and Bruss, M. L. (1997): Clinical Biochemistry of domestic animals. $5^{\text {th }}$ ed Academic press Inc. San Diego, New York, Berkeley, London, Sydney, Tokyo, Toronto. pp.580-680.

Lindsay, W. L. and Norvell, W. A.(1969): Equilibrium relationships of $\mathrm{Zn}^{2+}, \mathrm{Fe}^{3+}, \mathrm{Ca}^{2+}$ and $\mathrm{H}^{+}$with EDTA and DTPA in soils. Proc. Soil Soc. USA, 33-62.

Mark, J.H. and Mark, J.H.Jr. (2003): Water and Wastewater Technology. Asoke K.Ghossh, Prentice-Hall of India Private Limited New Delhi.

Mobark, M. G. and El-Bealawy, M. A. (2002): 
Hypophosphatemic hemoglobinuria and gastrointestinal nematode correlation in buffaloes and approach to treatment. J. Egyptian Vet. Med. Assoc., 62: (1)179-186.

Nassif, N. M. (1995): Nutritional problems affecting calcium, phosphorus and magnesium metabolism in Egyptian cattle and buffaloes. Ph.D Thesis Fac. Vet. Med. Zag. Univ., Egypt.

Page, A. L. (1982): Methods of soil analysis part,2 Am. Soc. Agron. Inc. Madison, Wiscosin USA.

Pandey, N. N. and Misra, S. K. (1987): Clinico-Biochemiczl studies of nutritional hemoglobinuria in buffaloes and therapy. Ind. Vet. J., 64: 39-43.

Pirzada, W. H.; Hussain, M. and Khan, K. N. M. (1989): A note on parturient haemoglobinuria in buffaloes. J. Anim. Hlth. Prod., 9: 20-23.

Radostits, O. M; Blood, D. C. and Gay, C. C. (2003): Vet. Medicine, A textbook of the diseases of cattle, sheep, pigs, goats and horse. $10^{\text {th }}$ ed. Bailliere Timdall pp.1727.

Rizk, H. I.; Kamel, A. A. and Abdel Razek, M. S. (1999): Biochemical changes in subclinical cases associated with phosphrus deficiency in buffaloes at Sharkia Governorate. J. Vet. Med. Res., 1: 165-174.

Schalm, O. W. (1986): A Text Book of Physiology. $5^{\text {th }}$ ed. Lea and Febiger, Philadelphia USA.

Selim, H. M.; Attia, H. and Abd-Allal, A. A.M. (1998): Field investigations on hypophosphatemia in Egyptian buffaloes: Risk factors, clinical, haematological and biochemical studies with trial of treatment. $8^{\text {th }}$ Sci. Con. Fac. Vet. Med. Assiut Univ. Egypt. 543-557.

Selvin, W. (1996): Statistical analysis of Epidemiological Data, $2^{\text {nd }}$ ed. Oxford Univ. pp.44-78.

Smith, B. P. (1996): Large Animal Internal Medicine. $2^{\text {nd }}$ ed. C.V. Mosby Company. St. Louis, Baltimore, Phadelphia, Toronte.

Soltan, P. (1985): Use of ammonium bicarbonate DTPA soil test to evaluate elemental availability and toxicity. Commun Soil Sci. Plant Analy., 16 (3): 323.

Udal, R. H. (1992): The Practice of Veterinary Medicine. $3^{\text {rd }}$ Ind. ed. Oxford and IBH, New Delhi.

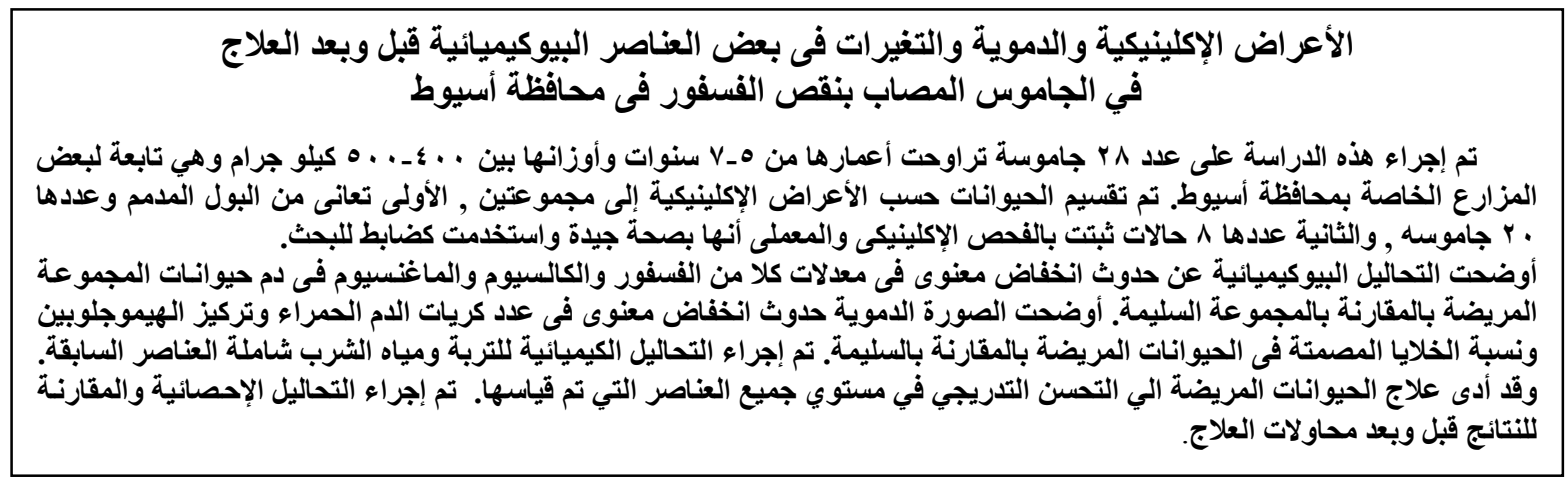

